\title{
Farming System Characterization of Arsizone: Case of Small-Scale Farming
}

\author{
Tamrat Gebiso Challa ${ }^{1,}$, Aman Nebo Tibesso ${ }^{1}$, Ashebir Tsegayie Mamo² \\ ${ }^{1}$ Agricultural Economics and Extension Directorate, Oromia Agricultural Research Institute, Asella, Ethiopia \\ ${ }^{2}$ Agricultural Engineering Directorate, Oromia Agricultural Research Institute, Asella, Ethiopia
}

Email address:

tameulove@yahoo.com (T. G. Challa)

${ }^{*}$ Corresponding author

\section{To cite this article:}

Tamrat Gebiso Challa, Aman Nebo Tibesso, Ashebir Tsegayie Mamo. Farming System Characterization of Arsizone: Case of Small-Scale Farming. American Journal of Environmental and Resource Economics. Vol. 4, No. 1, 2019, pp. 12-24. doi: 10.11648/j.ajere.20190401.12

Received: November 2, 2018; Accepted: February 1, 2019; Published: February 28, 2019

\begin{abstract}
Precise technological intervention and policy support needs identification and characterization of farm types. Therefore, farming system characterization is a vital activity for agricultural technologies generators or researchers, development practitioners and policy makers. Therefore, this farming system characterization research activity was initiated with objectives of identifying and characterizing the crop production system, identifying and prioritizing the major production system of agriculture in Arsi zone and to forward the possible intervention mechanisms for each farming typology. In general the farming system in Arsi zone is a crop-livestock mixed farming with small amount of lowland pastoralists. In this research further classification of farming typologies were identified. Accordingly, around seven broadly categorized farming typologies were identified which are lowland agro-pastoral, coffee-khat tree based, irrigation based, highland barley-root crop based maize-sorghum based, mechanized wheat belt farm type and non-mechanized wheat belt. The production potentials and constraints for each farming system typology were also discussed in this research output report. Constraints that could be tackled by research centers and development practitioners like office of agriculture and natural resource development, livestock resource development, irrigation development offices and support institutions like cooperatives and credit institutions were identified and prioritized. Though there is tendency of hasty generalization of Arsi zone as wheat enterprise specialized farming typology from policy makers, in this research finding it was recognized that Arsi zone has a diversified farming system that need multiple solutions from different experts and disciplines.
\end{abstract}

Keywords: Farming System Characterization, Small Scale Farming, Farming Typologies, Arsi Zone, Oromia Regional State

\section{Background and Justification}

There is high demand increment for food self-sufficiency all over the world and especially critical for developing countries. To be successful in this direction, enabling the small-scale farmers to produce to their maximum need is unquestionable. Therefore, researchers should search for agricultural technologies which made agriculture more economically viable and policy makers also should make intervention for such development [1]. In turn, precise technological intervention and policy support needs identification and characterization of farm types.

Farming system is described as a unit consisting of a human group (usually a household) and the resources it manages in its environment, involving the direct production of plant and/or animal products [2]. Assortment/typology of farming system is dictated by climate, production goals and culture of a society. Specially, the classification of the farming situations of developing regions may be as varied as - available natural resource base, climate, landscape, farm size, tenure and organization, dominant pattern of farm activities and household livelihoods, which determine the intensity of production and integration of crops, livestock and other activities and use of improved agricultural mechanization technologies [3-4] Further explained that the factors that define/determine farm typology vary greatly from study to study and/or from region to region which may be as diverse as agro ecological, socio-economic, managerial, infrastructural and broader issues of livelihoods. But 
unfortunately, both in agricultural and social sciences, complexity and diversity have remained ignored and undervalued, and excluded from government statistics and policy framework [5]. The heterogeneity in production system and agricultural technology utilization across different regions as well as variation in different farms are influenced by a host of biophysical (e.g. climate, soil fertility, slope etc.) and/or socio-economic (e.g. preferences, prices, production objectives etc.) and agricultural extension services factors [6].

From time to time, agriculture in developing countries has assumed commercial and mechanized proportion, replacing its traditionally subsistence and hand and hoe nature of dealing with agriculture. Hence, farm typology delineation based on improved technology intervention seems to be a pragmatic/realistic approach. Developing a typology constitutes an essential step in any realistic evaluation of the constraints and opportunities that exist within farm households for forwarding appropriate technological and policy interventions [7-9]. So far there are no such activities attempt to characterize the farming system of the area. Keeping this view in mind, an attempt to identify, characterize and evaluate predominant farming systems and agricultural mechanization technologies utilized in Arsi zone of Oromia National Regional State was executed with specific objectives of identifying an overall understanding of farming system of the area, identifying key/important areas of intervention with currently at hand available agricultural technologies and identifying key/important priority areas of agricultural technologies research.

\section{Research Methodology}

\subsection{Description of the Study Areas}

The research was conducted in Arsi zone. Arsi was purposively selected since it is the main station of Asella agricultural engineering research center and most of the center's interventions were in this zone. Arsi Zone is found in the central part of the Oromia National Regional State. The zone astronomically lies between $6^{0} 45^{\prime} \mathrm{N}$ to $8^{0} 58^{\circ} \mathrm{N}$ and $38^{\circ} 32 \mathrm{E}$ to $40^{\circ} 50^{\prime} \mathrm{E}$. It shares borderlines with west Arsi, Bale, west/Hararghe, and east Shewa zones. It has 25 administrative districts including one especial district. Asela is the capital town of the Zone. It is located at $175 \mathrm{~km}$ from Finfinne on Finfinne-Adama-Bale Robe main road.

Because of its great diversity in altitude, Arsi zone has great physiographic diversity. Based on the altitude there are four major identified physiographic divisions. The first one is the cool agro-climatic zone with altitude of above 3500masl, which covers the highest altitudes areas of the zone and constitutes about $2.74 \%$ of the total area of the zone. The second one is the cool temperate agro-climatic zone that includes the mountain ranges, massifs and high plateaus of Arsi $(2500-3500 \mathrm{~m})$ lies in the central part of the zone, stretching from the border of NNPSE (Nations, Nationalities and People of Southern Ethiopia) to Aseko district and belongs to the Arsi-Bale Massifs and covers about $22.74 \%$ of the total area. The third is the warm temperate agro-climatic zone (1500-2500m), which comprises low plateaus of the zone and covers about the $49.60 \%$ of zonal land surface while the fourth is lowlands of the zone (less than $1500 \mathrm{~m}$ ) constitute about $24.92 \%$ of the total area of the zone. This physiographic region of the zone is found in the Awash River valleys and southeastern lowlands. In general, the zone has the lowest altitude in extreme east of Seru district located in Wabe gorge with 805 masl and highest point on peak of mount Kaka 4195masl.

There are three dominant soil types in Arsi zone. These are: the Chromic and PellicVertisols having characteristics of water holding and heaviness for plowing during rainy seasons due to high clay content and it covers about $30 \%$; the Cambisols (23\%) dominantly occur on the steep slopes and are often shallow or have many rock outcrops and those developed on gentler slopes, however, have good base saturation and fertility and can highly be used for agricultural purposes; the third Luvisols which is good for agriculture with base saturation and weather able minerals and dominant on the high land parts covering about $13 \%$ of total area of the zone and lastly Lithosols is another soil type having good base saturation and fertility status and constituting about $6 \%$ of total and Fluvisols, constitutes about $2 \%$ of the total soil groups' coverage, and found in the lowland parts of Gololcha, Merti \& ZiwayDugda districts of the zone [10].

\subsection{Data Type, Source and Method of Collection}

Both primary and secondary data sources were employed in this research. Primary data sources were farmers, agricultural and natural resource development offices rural land administration offices, different NGOs and stakeholders working on rural development. Secondary data were collected from different research output materials and other official reports of different offices. In general data were collected by Rapid Rural Appraisal (RRA) and Participatory Rural Appraisal (PRA) methods and household level interview methods through structured and unstructured survey schedule and focus group discussion and key informants (table 1-2).

\subsection{Sample and Sampling Mechanism}

Multi-stage sampling technique was used to select districts and peasant associations (PAs). Even though it was tried to stratify the zone into three based on traditional agroecological based classifications as highland, mid highland and lowland, considering the accessibilities and other production factors which have impacts on farming system characteristics, the zone was further stratified as mid highland wheat-belt and mechanized areas, high land barely belt areas, mid to low land teff-maize and spices majoring areas, mid altitude heavy soil areas, lowland maize majoring areas, mid highland and highland un mechanized wheatbarley belt areas and coffee and fruits majoring areas. From each cluster one district was sampled and from each district 
one or two peasant associations were selected for FGD. A total of 15 farmers' FGD were held with each group having eight to fifteen group members who were systematically selected based on their farming experience, gender, educational background and etc. discussion with experts from each areas of agriculture, natural resource management, and livestock were also conducted at each level. Finally, household level interview was conducted to supplement those community level data.

Table 1. Districts' basic information: agro-ecology and altitudes.

\begin{tabular}{llllll}
\hline Percent of agro-ecology & & & & \\
\hline $\begin{array}{l}\text { List of } \\
\text { district }\end{array}$ & Highland & $\begin{array}{l}\text { Mid- } \\
\text { highland }\end{array}$ & Lowlands & $\begin{array}{l}\text { High } \\
\text { alt. }\end{array}$ & $\begin{array}{l}\text { Low } \\
\text { alt. }\end{array}$ \\
\hline Lemunabilbilo & $80 \%$ & $20.00 \%$ & $0.00 \%$ & 4180 & 1500 \\
Shirka & $24 \%$ & $56.00 \%$ & $20 \%$ & 3700 & 500 \\
Zuwaydugda & $0 \%$ & $10.30 \%$ & $89.7 \%$ & 1750 & 1600 \\
Hetosa & $26 \%$ & $47.80 \%$ & $26 \%$ & 400 & 1700 \\
Arsi-robe & $24 \%$ & $62.00 \%$ & $14 \%$ & 1150 & 800 \\
Cholle & $50 \%$ & $22 \%$ & $28 \%$ & 3574 & 1040 \\
Merti & $10 \%$ & $29 \%$ & $61 \%$ & NA & NA \\
\hline
\end{tabular}

Source: respective district's office of Agriculture and rural development NA: not available

Table 2. Districts' Temperature and rainfall of the sample districts.

\begin{tabular}{lll}
\hline District & Averagerainfall & Average temperature \\
\hline Lemunabilbilo & 1100 & 16 \\
Shirka & 1000 & 12.50 \\
Zuway-dugda & 650 & 25.50 \\
Hetosa & 800 & 21.00 \\
Arsi-robe & 1000 & 22.50 \\
Cholle & 1000 & 16 \\
Merti & NA & 26 \\
\hline
\end{tabular}

Source: respective district's office of Agriculture and rural development NA: not available

\subsection{Data Analysis Method}

Data analysis technique to be used in a research is determined by types of data collected and purpose of research output (report). Therefore, in our case since the data were more of qualitative in nature, descriptive and inferential statistics such as mean, median, cross tabulations and bargraph methods of analysis were utilized in this study. The qualitative data collected through FGD, KII and transect walk were analyzed qualitatively using narration methods.

\section{Results and Discussion}

\subsection{Socioeconomic Characteristics and Resource Ownership of Households}

Socioeconomic characteristics of the household include age of household, marital status of household head, educational background, total family size, male and female family size, number of hired labor, participation on non-farm and off-farm activities, and the like.

Accordingly, around 53 and 45 percent of the sampled households were Muslims and Orthodox Christianity followers respectively. Around 94 percent of the household was male headed and the rest 6 percent was female headed. The mean age of the household head was around 45 years while the mean educational status was 5.28years of education. Household's spouse educational status was found to be lower than that of household head which was 2.8 years of education. On average there was one family member which is not educated. There were 6.26 family members per a household on average with standard deviation of 2.26. The number of male and female family members per a household was found to be 3.45 and 2.81 respectively (Table 3 ).

Table 3. Socioeconomic profile of sample farm households in Arsi zone.

\begin{tabular}{|c|c|c|c|c|c|}
\hline No. & Variable & Minimum & Maximum & Mean value & Std. Deviation \\
\hline 1. & Total Family size & 1 & 14 & 6.26 & 2.26 \\
\hline 2. & Male family size & 0 & 9 & 3.45 & 1.68 \\
\hline 3. & Female family size & 0 & 7 & 2.81 & 1.50 \\
\hline 4. & House number & 1 & 1.3 & 2.70 & 1.66 \\
\hline 5. & Adult man-equivalent & 0.8 & 7.90 & 3.28 & 1.41 \\
\hline 6. & Livestock (TLU) & 0 & 14.69 & 7.54 & 1.84 \\
\hline 7. & Total land holding & 0.13 & 11 & 2.39 & 1.80 \\
\hline 8. & Total cultivated land & 0 & 12 & 2.33 & 1.76 \\
\hline
\end{tabular}

Majority of the household (40.67\% of the households) have land size between 1 and 2 hectare while only around 3 percent have landholding of above five hectares. In general more than $75 \%$ of the households have landholdings of less or equal to two hectares only (Table 4). The mean landholding of households was 2.39 ha with mean cultivated land size of 2.33 ha. When we see the land use pattern, land allocated for crop production accounts for large proportion followed by grazing land and residential land each having mean of 1.8 ha, 0.28 ha and 0.18 ha respectively. Forest land, irrigated farm and degraded land (land of no use) each accounts for mean of 0.07ha, 0.04ha and 0.03ha per household. Each household possessed livestock of mean 7.54 TLU. The total mean number of houses that household possessed was 2.7 houses. Considerable percent of households possessed other assets like television, cell-phone, solar cells for house lightening and mobile charging etc. 
Table 4. Landholding Distribution by Household percent in Arsi zone.

\begin{tabular}{llll}
\hline Range of landholding & Percent of holders & Std. Deviation & Cumulative Average \\
\hline Less than 0.5 hectare & 9.83 & 7.2 & 9.83 \\
Between 0.5ha and 1ha & 25.4 & 13.65 & 35.23 \\
Between 1ha and 2ha & 40.67 & 23.17 & 75.9 \\
Between 2ha to 5ha & 20.9 & 16.72 & 96.8 \\
Above 5ha & 3.2 & 3.52 & 100 \\
\hline
\end{tabular}

Source: Districts office of agriculture and natural resources development

The result revealed that there was considerable land allocation for forest and grazing while the degraded (land of no use) is also significant which is because of soil degradation due to miss-use of the land. From both FGD and household level survey, there is no communal grazing land except in agro-pastoral areas of Merti district (Table 5).

Table 5. Own land use pattern of household.

\begin{tabular}{llll}
\hline No. & Land use & Mean value (ha) & Std. Deviation of mean \\
\hline 1. & Rain fed crop production & 1.77 & 1.4 \\
2. & Grazing land & 0.28 & 0.49 \\
3. & Residential land & 0.18 & 0.17 \\
4. & Forest land & 0.07 & 0.22 \\
5. & Irrigated crop production & 0.04 & 0.14 \\
6. & Degraded land & 0.03 & 0.11 \\
7. & Others & 0.01 & 0.04 \\
\hline
\end{tabular}

Source: own household survey

\subsection{Enabling Institutional Facilities for Agricultural Production in Arsi}

In order to the farmers to produce, there are many enabling institutional facilities that have to function properly. These facilities includes but not limited to market, potable water, communication facilities, rural energy (lightening, and cooking), extension service provisions, credit facilities and so on. Most farmers get market information (about 80\%) but it is not from well-known sources. Farmers do not trust information from DAs and most information sources were neighboring farmers $(25.8 \%)$ followed by traders $(12.1 \%)$ while only $3.7 \%$ of farmers get market information from cooperatives. This shows how the cooperatives are not functional in agricultural output trading. Most market related constraints would have been answered by farmers' primary cooperatives and unions but from FGD and individual household survey results, the cooperatives tend to profit making institutions and their goals were not serving the interest of their members but maximizing their profit.

Only $40.5 \%$ of the households have access to potable water while $27.4 \%$ have electricity power either grid or solar and more than $75 \%$ of them has cell phone. In the two years period around $37 \%$ of total households have used credit services from different sources for different purposes. About 54 percent of the households do not need credit because of different reasons like religious cases or they do have enough resources and cash while the rest were interested in credit using. Around 37 percent of the total sample was using credit for different purposes. The major credit service using purpose was purchasing agricultural inputs like fertilizer and seed followed by buying animals for small fattening or breeding and petty trading. Therefore, this indicates that credit facility is one of important services to be provided to farmers especially for resource poor farmers (table 6).

Table 6. Credit Service Use and Purposes of Credit.

\begin{tabular}{lll}
\hline No. & Description of Variable & Percent \\
\hline 1. & Use credit service & 37.4 \\
2. & To purchase fertilizer & 38 \\
3. & To purchase improved seed & 15.5 \\
4. & For schooling children & 1.4 \\
5. & For petty trade & 5.6 \\
6. & Buy animal for fattening/breeding & 35.2 \\
7. & Others & 4 \\
\hline
\end{tabular}

The major problems encountered in using credit service were high interest rate and collateral problems each ranked as first by 25.8 and 12.6 percent of respondents (Table 7). Shortage of money (absence of amount of money that a household need to get) and absence of credit sources in accessible area were also ranked third and fourth respectively.

Table 7. Problems related to credit service provisions.

\begin{tabular}{lll}
\hline Description of problem & Frequency & Percentage \\
\hline High interest rate & 48 & 25.8 \\
Collateral problem & 24 & 12.6 \\
Limited money (money availability) & 10 & 5.3 \\
Absence of credit sources & 5 & 2.6 \\
I do not need credit & 102 & 53.7 \\
Total $(\mathrm{N})$ & 190 & 100 \\
\hline
\end{tabular}

The respondents' perception was assessed on the strength of extension service provision by different bodies and according to most respondents' perception the service was strongly biased towards biological aspects of crop production and slightly to livestock production (Table 8-9). The extension services on natural resource conservation and agricultural engineering technologies were ranked as very poor. 
Table 8. Extension Service Provision Rate for Crop and Livestock Production.

\begin{tabular}{lllll}
\hline \multirow{2}{*}{ Rate of service } & Crop production & & Livestock production \\
\cline { 2 - 5 } & Percent & Cumulative percent & Percent & Cumulative percent \\
\hline Very strong & 6.3 & 6.3 & 2.1 & 2.1 \\
Strong & 47.9 & 54.5 & 41.1 & 43.2 \\
In between & 36.3 & 91.0 & 20.00 & 78.9 \\
Weak & 8.9 & 100 & 1.1 & 98.9 \\
Very weak & 0 & 0 & & 100 \\
\hline
\end{tabular}

Table 9. Extension Service Provision Rate on Natural Resource and Agricultural Engineering

\begin{tabular}{|c|c|c|c|c|}
\hline \multirow{2}{*}{ Rate of service } & \multicolumn{2}{|c|}{ NR conservation } & \multicolumn{2}{|c|}{ Agricultural Engineering } \\
\hline & \multicolumn{2}{|c|}{ Percent Cumulative percent } & \multicolumn{2}{|c|}{ Percent Cumulative percent } \\
\hline Very strong & 0.5 & 0.5 & 0.5 & 0.5 \\
\hline Strong & 28.4 & 28.9 & 6.8 & 7.4 \\
\hline In between & 50.5 & 79.5 & 18.9 & 26.3 \\
\hline Weak & 18.9 & 98.4 & 61.1 & 87.4 \\
\hline Very weak & 1.6 & 100 & 12.6 & 100 \\
\hline
\end{tabular}

The result of the survey revealed that more than $73 \%$ of the respondents perceived that the extension service on mechanization was below average which was weak or very weak. The FGD result and experts discussion output also revealed that there was weak extension services provision on agricultural engineering technologies because of structural problem where there was no expert on this discipline even at office level (neither district nor zonal level) which means there is no concerned body in any of government extension wings.

\subsection{Households Income Sources and Livelihood Diversification}

Most households have diversified income sources. The diversification could be by enterprise diversification or engaging into different off-farm and non-farm activities. Both FGD and household survey result was used to rank the income sources. The main household income sources were identified to be crop production, cattle rearing and small ruminants rearing. The households' income sources and livelihood diversification across farming system typologies were given in table 8 below. Dairy production was the more significant income source in Shirka district with annual mean value of 5187.69ETB which revealed that there is high potential for this sub-sector.

Even though there is high diversity in important enterprises, the major livelihoods in all farming systems were crop production, cattle, small ruminants (sheep for mid and highland areas and goats for lowland agro-pastoral of Merti and maize-majoring Zuwaydugda areas), poultry birds, and off-farm activities. But in each sub-farming system there is a kind of specialization on different enterprises and off-farm activities especially where there were shortage of land both for livestock keeping and crop production (table 10).

The small ruminant production/ rearing (sheep and goat) activities were dominant in Lemu-bilbilo, Zuway-dugda and Shirka with mean value of 2047.17, 1267.69 and 2091.43 ETB respectively. When we see specific potential for the enterprises, sheep is dominant in Lemu-bilbilo, because of highland agro-ecology; goats are dominant in Zuway-dugda while both sheep and goats have equal potential in Shirka districts. Therefore, attention should be given accordingly to improve the development of each sub-sector. In all agroecologies small ruminants and poultry birds were listed as most important but less recognized enterprises. Small fattening (both small ruminants and cattle) has significant household income share in Shirka, Lemi-Bilbilo and Hetosa districts with mean annual value of 3784.6, 1698.11, 1457.14 ETB respectively. In Hetosa even though livestock population was relatively small, the survey result revealed that there was good practice of fattening at household level.

In general the mean off-farm income of the zone was 4018.32 ETB but with greater standard deviation (9488.18). Non-farm income sources have also significant contribution in income of households. For instance, trading different commodities like household consumables, livestock, crop and working on others farm as a laborer and as other activities were the major income sources. In Lemunabilbilo district trading has mean annual contribution of 2377.36 ETB while it has mean annual contribution of 2307.69 ETB in Shirka district while working as a labor on either farm or non-farm activities has contribution to income in Lemunabilbilo, Merti and Zuway-dugda with mean value of $279.25,250$ and $142.86 \mathrm{ETB}$ per annum respectively.

Table 10. Mean Income and their Sources Distribution across Districts in Arsi Zone.

\begin{tabular}{|c|c|c|c|c|c|c|c|c|}
\hline \multicolumn{9}{|c|}{ Mean Annual Income by Types of Farming System } \\
\hline Income Sources & 1 & 2 & 3 & 4 & 5 & 6 & 7 & Total \\
\hline Crop production & 29992 & 16226 & 19171 & 20547 & 6658 & 9608 & 5433 & 19971 \\
\hline Cattle rearing & 5613 & 7692 & 6237 & 6557 & 2717 & 4292 & 3858 & 5492 \\
\hline Beekeeping & 30 & 0 & 349 & 48.57 & 0 & 246 & 17 & 114 \\
\hline Trading & 2377 & 2308 & 171 & 171 & 56 & 542 & 0 & 958 \\
\hline Dairy product & 236 & 5188 & 200 & 171 & 67 & 0 & 292 & 514 \\
\hline Small ruminant & 2047 & 1268 & 2091 & 377 & 644 & 600 & 379 & 1273 \\
\hline Laborer & 279 & 0 & 143 & 0 & 0 & 0 & 250 & 120 \\
\hline
\end{tabular}




\begin{tabular}{|c|c|c|c|c|c|c|c|c|}
\hline \multicolumn{9}{|c|}{ Mean Annual Income by Types of Farming System } \\
\hline Income Sources & 1 & 2 & 3 & 4 & 5 & 6 & 7 & Total \\
\hline Fattening & 1698 & 3785 & 0 & 1457 & 0 & 0 & 917 & 1059 \\
\hline Off-farm income & 6863 & 10602 & 457 & 3266 & 100 & 4679 & 1458 & 4018 \\
\hline Poultry & 285 & 385 & 269 & 580 & 222 & 196 & 253 & 324 \\
\hline Rent house & 848 & 3563 & 143 & 0 & 44 & 408 & 42 & 565 \\
\hline
\end{tabular}

Key: 1=Barley based, 2=Teff based, 3=Irrigated, 4= Mechanized, 5= un-mechanized, $6=$ Coffee-khat tree based and $7=$ Lowland farming typology

Source: own computation from survey data

\subsection{Households' Farm Labor Availability}

In most subsistence farming the labor sources are family members. Each of the household has an average of 3.28 adult man equivalent family labors. Most respondent (70\%) households responded that they faced labor shortage on at least one of their farm operation. Harvesting/threshing was the most important operation where most farmers face labor shortage $(47.4 \%$ of respondents) followed by weeding/cultivation, land preparation and planting facing
$31.6 \%$ and $30 \%$ and $23.7 \%$ of farmers respectively. The major coping mechanisms used by farmers during labor shortage were using labor exchange/wonfel (45.8\%), employing casual labor $(32.10 \%)$, and employing permanent labor (13.2\%). Some farmers (around 6.3\% and 4.2\%) households rent in agricultural machineries mainly tractor and combine harvester and rent out their farmlands as labor shortage coping mechanisms respectively (table 11).

Table 11. Labor Shortage, Coping Mechanisms in Arsi zone.

\begin{tabular}{llll}
\hline & Description & Percent of respondent & No. \\
\cline { 3 - 4 } Coping mechanism & Yes & 30 \\
& Face labor shortage & 70 & 54.2 \\
& Use labor exchange/wenfel & 45.8 & 67.9 \\
& Employ casual labor & 32.1 & 86.8 \\
& Employ permanent labor & 13.2 & 93.7 \\
& Rent agricultural machineries & 6.3 & 95.8 \\
& Rent out farmland & 4.2 & 75.8 \\
& Low labor quality & 24.2 & 63.2 \\
\hline
\end{tabular}

Source: own survey data of 2017

\subsection{The Farming System Typologies of Arsi Zone}

The farming system of the zone can be broadly classified into two major clusters as crop-livestock mixed farming and the pastoral/agro-pastoral farming system. The pastoral/agro-pastoral farming system is found in lowland areas of Merti and Gololcha districts. The crop-livestock mixed farming is further clustered into three sub-farming clusters as cereal based, irrigation-based and coffee-khat (chat) tree based farming. The cereal sub-cluster is also further clustered into barley-root crops based, wheat-teff based and maize-sorghum based farming system. The wheatteff belt farming sub cluster was also further clustered into mechanized and non-mechanized farming sub-clusters. There is also further clustering based on number of cropping per a year as double cropping and single cropping. Most barleyroot crops based and part of wheat-teff farming clusters have two rain fed cropping seasons. The rest sub-clusters have single cropping season unless supported by irrigation.

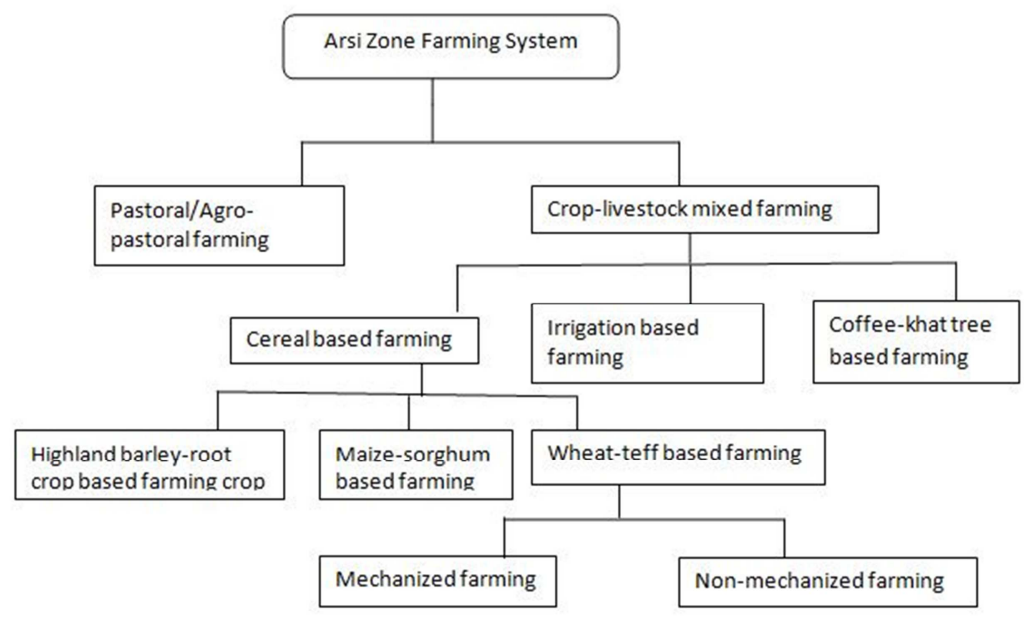

Figure 1. Broad hierarchal classification of farming system typologies in Arsi zone. 


\subsection{Characteristics of Sub- Clusters Farming System Typologies}

\subsubsection{Barley-Root Crops Based Farming System}

This farming system is found in highland and mid highlands of Lemunabilbilo, Honkolo-wabe, Shirka, Tiyo and the like which follows the basis/massifs of Chilalo mountain. Previously in this sub-cluster most land was under communal pasture and gradually due to population pressure the pasture land become under crop production. The major crop type in this sub-clusters were barley, wheat and rain fed based root crops like potato, carrot, beetroot garlic etc. In addition large varieties of other crops especially pulses like faba bean, field pea, and lentils, rapeseeds etc. are grown in this farming system. These crops were used as rotational crops for cereal crops to maintain the fertility of soil.

Malt barley is the most favorable sub-enterprise in this sub-cluster and it accounts for about $36 \%$ of total land allocation while barley as a general including food barley and malt barley is grown on about $54 \%$ of the total farm land followed by wheat, linseed and root crops each covering about $27 \%, 8 \%$ and $4 \%$ of total land respectively. Pulse crops like faba bean, lentils and field peas were also grown on considerable size of farmland covering around 7.5 percent of total cultivated land. Mean productivity of malt barley was 39.45qt per hectare and for food barley was 19.51 which shown that there is high potential for malt barley production in this area. Livestock production specially cattle breeding, sheep, dairy production and beekeeping were also the most important enterprises in this sub-cluster farming system.

Major production constraints of the sub-cluster

Pair-wise ranking was employed to prioritize the major production constraints of the sub-sector during FGD with farmers and discussion with agricultural experts at district level. Accordingly, in malt barley production the major production constraints were absence of high yielding varieties (variety options), and lack of mechanization technologies. The use of heavy duty machines like tractors and combine harvester is difficult because of land topography, and farmland fragmentation. Crop disease (rust) was the major constraint for wheat growing farmers. This problem resulted into other problems like increase in production cost, low productivity and crop complete devastation (failure) in most cases (table 12).

In general about eight production constraints of this subcluster were identified by farmers and they were ranked according to their importance. In root-crop production the major constraint was mentioned to be storage and market related. The perishability nature of the crop and lack of storage or processing technologies lead the producers to sell their produce at unreasonably lower price during peak production seasons and huge postharvest losses.

Table 12. Major crop production constraints in barely-root crops based sub farming system of Arsi zone.

\begin{tabular}{|c|c|c|}
\hline Major constraints: & Score in pair-wise ranking & Rank \\
\hline 1. Absence of high yielding malt barley variety & 8 & 1 \\
\hline 2. Crop diseases (wheat rust) & 6 & 2 \\
\hline 3. Lack of mechanization technologies (chemical sprayer etc) & 4 & 3 \\
\hline 4. Absence of varietal option (high yielding, disease resistant) & 4 & 3 \\
\hline 5. Increase in input price (fertilizer, weed killers and other pesticides) & 3 & 4 \\
\hline 6. Improved seed supply shortage & 2 & 5 \\
\hline 7. Erratic rainfall & 1 & 6 \\
\hline 9. Perishability and lack of storage facilities for vegetable (root crops) & 1 & 6 \\
\hline
\end{tabular}

\subsubsection{Wheat-Teff Based Sub-Cluster of Farming System}

This farming system typology is found in mid highlands/sub-tropical of the zone and mostly known by growing wheat, teff, barley, oilseeds and spices crops. In Arsi zone this sub-cluster is further classified into two subfarming systems as highly mechanized farming cluster and non-mechanized farming system. Mechanized farms are found in most parts of Hetosa, parts of Lode-Hetosa, pocket areas of Tiyo, Lemunabilbilo and DigalunaTijo, and most parts of Munesa districts. Especially in Hetosa, around 50\% and $100 \%$ of the households are tractor and combine harvester users respectively. Wheat productivity was also the highest in this sub-sector with average yield of 45 quintals per hectare. In these mechanized areas, wheat was predominantly grown year after year on the same farm and mono-cropping was one of the serious problem of this subcluster which was a cause for many other problems like soil fertility decrease, wheat crop disease (rust), and grass weed.
The soil of this sub-cluster was majorly black but not too heavy (medium) type.

The second sub-sector was non-mechanized cluster where wheat production has slightly higher share but other small seeded crops like teff and oilseeds like Niger seed, sunflower, linseed, and rape seeds and spices like black commune, hotpepper (largest share with $16 \%$ of total land allocation in Shirka) etc. have significant share of land allocation. Pulse crops like chickpea and lentils have also considerable land coverage but threatened by wilting pests. This sub-cluster is widely dominating in most areas of east part of Shirka, Dida'a and Arba-gugu districts. Use of BBM is common in most parts of the area where there is vertisol.

Major production constraints of wheat-teff and oilseeds based sub-cluster

Teff is being dominating in this area (shifting of enterprises from wheat and pulse crops to teff) because of change in both raining calendar and intensity. According to 
farmers in the area, since 10 to 15 years the rainfall becomes erratic, late entering and huge rain during months of August and September which causes water logging and leaching out of soil minerals and decreased soil fertility. Lack of improved seed for all crop types (almost complete absence for teff), high price of different chemicals compared to output price and land productivity, supply shortage for chemical, black marketing of chemicals where private traders set unreasonable price, supplying of either expired or wrong chemicals (table 13).

Table 13. Major crop production constraints in barely-root crops based sub farming system of Arsi zone.

\begin{tabular}{|c|c|c|c|c|}
\hline \multirow{2}{*}{ Major constraints: } & \multicolumn{2}{|c|}{ Score in pair-wise ranking } & \multicolumn{2}{|l|}{ Rank } \\
\hline & Mechanized & non-Mech. & Mechanized & Non-Mech. \\
\hline 1. Climate change & 4 & 9 & 6 & 1 \\
\hline 2. Mono-cropping & 9 & 0 & 1 & 8 \\
\hline 3. Crop diseases (Wheat rust, wilt etc.) & 8 & 3 & 2 & 5 \\
\hline 4. Seed related problems (type and amount) & 7 & 5 & 3 & 4 \\
\hline 5. Low soil fertility (NR degradation) & 3 & 8 & 7 & 2 \\
\hline 6. Invasive grass weed & 6 & 1 & 4 & 7 \\
\hline 8. Problem on vertisol management & 1 & 6 & 9 & 3 \\
\hline 9. Week extension service (technical aspects) & 2 & 4 & 8 & 5 \\
\hline 10. Absence of agricultural mechanization & 0 & 3 & 10 & 6 \\
\hline
\end{tabular}

Source: FGD and experts discussion at district level

According to the PRA result most production constraints are inter-related like the case of mono-cropping which is cause for invasive grass weed, poor soil fertility and aggravates wheat rust and other pests. Week extension service provision which is cause for low technical skill and knowledge, low awareness on agronomic practices was the major cause for poor vertisol management. Seed related problems include absence of improved seed for most alternative cash and other crops like pulse crops, oilseed, teff, hot-pepper and the like and absence of varietal options for some existing seeds. Even though pulse crops are known as a rotational crop to improve soil fertility and break mono-cropping problems by farmers, absence of disease resistant varietal options is pushing the enterprise out of production system. Land degradation, shortage of grazing land, continuous crop failure which result into absence of crop residue for animal feed are becoming the main causes for shortage in farm draught animal power (plowing and threshing).

\subsubsection{Large Seeded Cereals Maize-Sorghum Based Sub-Cluster Farming System}

This farming system was found in moderately hot subcluster of the zone including majority of Z/dugda, Dodota, Merti, Aseko, Gololcha, half of Chole and the like districts. The most important crop enterprises in this farming system are maize, sorghum, haricot bean, teff and others. The average landholding of this sub-cluster was 2.64ha per household. The soil fertility is relatively good but crop production is challenged mostly by low moisture. Except $\mathrm{Z} /$ dugda and Dodota areas, this sub-cluster is characterized by low use of improved technologies (both mechanical and biological). To justify this data was collected both from office of agriculture and natural resource development and household survey. The result revealed that use of mechanical technologies (tractor and combine harvester) is almost nilbecause of different reasons like low awareness, accessibility, low service purchasing power of the farmers, and the like.

Major Production Constraints of Maize-Sorghum Based Farming System

Erratic rainfall and moisture stresses are the most important production constraint followed by high input prices like fertilizer, and chemicals, poor input supply system like timeliness, poor quality inputs due to illegal traders control over the market, and supply shortage, crop diseases like smut, stock borer (for maize), expansion of witch weed striga weed (severe in Merti and Chole areas), lack of mechanization technologies were the most important production constraints (Table 12). Similar way of pair-wise ranking was used to prioritize the production constraints for economically important crop enterprises. Therefore, there is a need for development of technologies for efficient use of water and improvement in soil moisture conserving technologies in the future and demonstration of at hand preharvest and harvest technologies like ARDU plows, small powered tractors, BBM and harvesting technologies like thresher is most important activities to be planned. On the other hand introduction of striga resistant sorghum and awareness creation should be the priority action (table 14).

Table 14. Prioritized major agricultural production constraints.

\begin{tabular}{lll}
\hline No. & Major constraints & Indexed Score \\
\hline 1. & Poor Inputs (chemicals, fertilizer, seed) supply system & 0.14 \\
2. & Crop pests (striga and poisoning grass weed in teff) & 0.19 \\
3. & Erratic rainfall and moisture stress & 0.19 \\
4. & Draught power shortage & 0.10 \\
5. & Backward mechanization technologies use & 0.14 \\
6. & Land degradation and poor soil fertility & 0.14 \\
7. & Wild animals & 0.10 \\
\hline
\end{tabular}


In $\mathrm{Z} /$ dugda district it was reported that teff (Eragrostistef) straw is not being used as animal feed because of deadly poisoning teff grass weed which kills livestock if consumed with teff straw. They reported they couldn't get any mechanism to control the weed and it is causing dual problem, loss of production and makes the straw out of use as animal feed.

\subsubsection{Rain Fed Coffee-Khat (Chat)-Tree Based Sub-Cluster Farming System}

This sub-cluster farming system is found in Merti,
Gololcha, Chole, Aseko, Guna districts. These districts are known for coffee production in the zone but only Gololcha coffee is recognized in national market. The main enterprises in this sub-cluster are perennial tree plants like coffee, khat, banana and other fruits like orange and lemon. The average landholding of the area is around $1.44 \mathrm{ha} / \mathrm{HH}$. From the survey result conducted data, around 30 percent of total landholding was covered by coffee which is the largest share followed by maize which is around 25 percent of total landholding (Table 15).

Table 15. Landholding and allocation in Coffee-khat (chat)-Tree Based Farming.

\begin{tabular}{llll}
\hline No. & Description of Variable & Mean Value & Std. Deviation \\
\hline 1. & Total landholding & $1.44 \mathrm{ha}$ & 0.52 \\
2. & Maize farm & $0.36 \mathrm{ha}$ & 0.25 \\
3. & Coffee farm & $0.43 \mathrm{ha}$ & 0.32 \\
4. & Share of coffee farm from total farm land & $29.73 \%$ & \\
\hline
\end{tabular}

Source: data from FGD participants

Coffee is not only the crop grown on more share of land but it is the most and first ranked livelihood activity in the area followed by other cereal crops like maize, sorghum and teff. Khat is the third most important livelihood activity next to cereal crops production.

Major production constraints in Coffee-khat (chat)-Tree Based Farming

The major coffee production constraints were categorized into two major groups by the farmers as production side and harvest and postharvest handling and market related constraints. From production side, the entire traditional production system is the main one. In this regard, there is no research and development intervention (support) which means there is no improvement in quality and productivity of coffee seed, production techniques, high disease incidence but no identified protection or treatment methods (no chemical or agronomic practices). In other hands, poor soil fertility, erratic rain fall, deforestation which causes loss of coffee shades were other pertinent constraints.

The second constraint category was market and institutional related problems which includes absence of coffee processing and storage facilities, absence of legal market outlets, and low price of produce. Farmers process and store their produces by skill and technologies they acquired traditionally. Except for Gololcha district, coffee produce of rest districts are not registered and recognized/legalized in national market. Therefore, farmers are forced to sell to coffee collectors and other illegal traders who set price themselves. The second production constraints (market related) is the most severe one which is much discouraging the producers. Because of this problem farmers reported that there is shift of enterprise from coffee to khat (replacing coffee farm by khat trees). Therefore, much has to be done on market development of the product before the farmers devastate their coffee farms and replace.

In this sub-cluster farming system since there is production of other cereals their production constraints were also identified and prioritized in order of their economic importance. Change in climatic conditions, crop pests like shoot fly, stock borer, and wheat rust were the most important constraints (table 16).

Table 16. Major production constraints in coffee-khat based farming system.

\begin{tabular}{lll}
\hline Production Constraints & Coffee production constraints & Rank \\
\hline Non-coffee crops farm constraints & No research and development intervention & 1 \\
\hline Erratic rainfall & Seed and other inputs supply shortage & 2 \\
Poor soil fertility b/c of high erosion \& & Poor natural resource base (soil and forest) & 3 \\
Limited farm size & Coffee disease & 4 \\
Chemicals supply and high prices & Poor market and postharvest handling facility & 5 \\
Invasive weed & Low price of coffee produce & 6 \\
\hline
\end{tabular}

\subsubsection{Irrigation Based Sub-Cluster Farming System}

Modern irrigation schemes are found in four districts of Arsi zone namely L/bilbilo, Tiyo, Zuway-dugda and Merti. For this research purpose irrigation based production constraints were collected using farmer FGD and household survey in Zuway-dugda district while discussion with districts experts was conducted in Merti and Zuway-dugda districts. Total landholding in this sub-cluster farming system was around 1.4ha per household. The farmers hold on average about 0.5 ha of irrigated farm. But from discussion made with districts' experts, FGD held with farmers and $\mathrm{HH}$ survey, it was understood that most irrigated farms were rented out to non-PA member individuals who migrates from 
neighboring districts and regions (Tigray, Amhara and SNNP). The major irrigated crops were potato, onion, cabbages, head cabbage, carrot, papaya, beet roots, garlic and the like. In some cases cereals like maize are also produced using irrigation system.

Major crop production constraints in irrigation Based subcluster farming system

The major production constraints were identified in this sub-cluster farming system. The most important ones were; high supply shortages for pesticides, fertilizers, and seeds. High price and ineffective chemicals, high involvement of brokers and illegal traders both in input supply and farm output selling, absence of credit facilities for resource poor farmers to get working capital and inactive involvements of irrigation users associations (producers' cooperatives) in input supplying and output marketing. Because of its relative remoteness, access to agricultural support institutions like research centers, seed enterprises, and mechanical technologies providers was another serious constraint of irrigated farm in Arbagugu districts like Merti. Furthermore, high postharvest loss and low price of products were another challenges due to poor technological intervention for storage preservation. Furthermore, excessive use of chemical fertilizers and pesticides were practiced which may cause contamination of ground table water and disturbs soil properties unless it is treated with natural fertilizers which may take long time. However, further specific research is needed to give more recommendation on this issue specifically.

\subsubsection{Agro-pastoral Sub-cluster Farming System}

This farming system is found in eastern part of Arsi zone. The registered pastoralist and agro-pastoralist kebeles (PAs) were found in Merti district. According to the report from district's office of agriculture and natural resource development there are two pastoralists and one agropastoralist PAs. The main staying livelihood of this farming system was livestock keeping. The major livestock types were cattle, goats, camel, equine animals and poultry. The agro-pastoralists are practicing crop production and the main crops were maize and sorghum. Large size of land was allocated to pasture/grazing land in this farming system at household level. According to data from district's rural land administration office, pasture land is greater than crop cultivated land by around 42 percent.

The main production constraints in this farming system were drought, which causes feed and water shortage, animal diseases and absence/shortage of health service centers, supply shortage of medicines, logistic problems at district level (like vehicle, budget for per diem ) to deliver services. Even though there is large number of camel population in the district, it was reported that there is low attention given to this sub-sector which can be demonstrated by no research and development interventions. To overcome the constraint in this area there must be joint plan between research centers, districts' agriculture office and livestock agency on water saving technologies, demonstration of short maturing and drought resistant forage varieties. Further study on ground water table should be conducted and wind and solar pump technologies should be introduced by agricultural engineering research centers.

\subsubsection{Peri-Urban Sub-Clustered Farming System Characteristics}

As everywhere in developing countries, there is high expansion of peri urban farming in Arsi zone due to urbanization. Two kinds of farmers in most peri urban areas exist: those who have their own farmland and produce themselves on their own farmlands, and those who are dwelling in towns but rent/shared in some farmlands and produce agricultural and livestock products. From discussion made with farmers and districts' experts, those living in peri urban areas and working on agricultural activities were the most updated farmers and technology user in both livestock and crop production. Their production goal is also market targeted; they have higher productivity per unit. But in the case of second group, even though they are using more inputs since they are not members of PA, and in most cases they work on farm as secondary activity, they do not get extension services (training and participation on demonstration activities) and they lack skill and knowledge and known by low productivity.

\subsection{Agricultural Mechanization Technology Use in Arsi Zone}

Absence of or supply shortage of agricultural mechanization technologies were the most important production constraint in almost all farming system of Arsi. In all farming system clusters shortage of animal feed resulted in farm power shortage which needs solution from agricultural mechanization by searching for alternative inanimate farm power.

In all wheat, barley and teff growing areas, even though farmers understood the importance of row planting, absence of row planting technologies were the most important bottleneck. There was misapplication of different types of chemicals reported from bureau of agriculture and natural resource development at each district. The existing chemical sprayer equipment (knapsack) which was carried on human's back is unsafe for the operator and tiresome. Therefore, in addition to training farmers on chemical application safety, modernizing/further mechanizing the technology was mentioned as a solution from experts (FGD at district level).

In areas where combine harvesting was not used because of availability or inaccessibility due to topography, harvesting and threshing/shelling technologies were the most important demanded technologies. Therefore, availing at hand technologies like walking behind wheat-barley harvester evaluated by Asella agricultural engineering research center, multi-crop thresher for wheat, barley, teff and sorghum and maize sheller should be the first priority action.

According to data from respective office of agricultural and natural resource development districts, there was no 
registered data for intermediate agricultural mechanization technologies and even in most districts the technologies were not known by experts except BBM use in almost all vertisol areas like DigelunaTijo, parts of Lemuna-Bilbilo, Shirka, Arsi-robe and the like. However, there is estimated number of farmers (in percent) who were using large mechanization technologies specially for crop production like tractor and combine harvesters. Combine harvester is entirely used for wheat crop because of two main reasons. The first reason was lodging nature of most barley crops and the second reason was that farmers don't want wastage of barley straw because of its palatability as animal feed (table 17).

Table 17. Agricultural mechanization technologies use status across districts.

\begin{tabular}{|c|c|c|c|c|c|c|}
\hline \multicolumn{7}{|c|}{ Percent of technology using households for technologies } \\
\hline No. & Districts & Tractor & Combiner & Cart & BBM & Warehouse* \\
\hline 1. & L/bilbilo & $7.5(5 \%)$ & $24.5(10 \%)$ & 20 & 1.9 & 5 \\
\hline 2. & Shirka & $0(0)$ & $0(5 \%)$ & 1 & 15.4 & 50 \\
\hline 3. & Z/dugda & $2.9(1 \%)$ & $8.6(1 \%)$ & 50 & 0 & 5 \\
\hline 4. & Hetosa & $85.7(55 \%)$ & $97.1(100 \%)$ & 5 & 0 & 40 \\
\hline 5. & A/robe & $0(20 \%)$ & $0(10 \%)$ & 2 & 44.4 & 20 \\
\hline 6. & Chole & $0(0)$ & $0(0)$ & 0 & 12.5 & 29 \\
\hline
\end{tabular}

Numbers in brackets are data from respective district's office agriculture while were computed from HH survey

*1 data is from HH survey result

$1 * *$ data is from district offices of agriculture and natural resources development

In non-mechanized farming system there were different reasons for not using intermediate or mechanization technologies. Lack of awareness, accessibility of the technologies, and inappropriateness of the topography, high price of services for tractor and combine harvester were the main constraints to use these technologies. Lack of awareness and accessibility of technologies were main constraints in wheat-teff based mixed farming system while affordability of the service prices specially for tractor and combine harvesting machineries were the main constraint in lowland areas of resource poor maize-sorghum based mixed farming system and some parts of wheat-teff based mixed farming system in Arsi-robe surrounding districts. Topography and lack of appropriate technologies for their topography was the most constraint in barley-root crops based sub-cluster farming system.

Most completed and on-going agricultural engineering research, pre-extension demonstration and pre-scaling up activities by Asella agricultural engineering research center were focusing on and biased towards highlands and midhighlands wheat-barley growing farming systems and little attention was given to lowland moisture stressed areas of the zone. Therefore, following expansion of drought from time to time in the zone, besides conserving soil and water resources, technologies that enable farmers/pastoralists/agro-pastoralists to use existing water efficiently should be given due attentions from researchers side while the existing at hand technologies should be identified and availed for demonstration and pre-scaling by concerned bodies.

\subsection{Farmers' Perception Towards Change in Farming Systems}

More than 84 percent of the total respondents perceived that there is change in their farming system since five years due to one or more factors. Out of these around 26 percent of them responded that the change they perceived is due to climate change which affected time of raining, amount of rain per season, consistency of rain while around 54 percent of them responded there is change in farming system due to awareness, skill and knowledge they get from extension services provided to them by different bodies on advantages of using production inputs both in cop production and livestock production which increased their level of fertilizer, improved seeds and livestock breeds, pesticides and agronomic practices like land preparation, row planting, weed management and mechanization technologies use. Considerable number of respondents also perceived the change due to crop diseases like wheat rust, sriga and smut (especially maize and sorghum farmers in Arbagugu districts like Chole and Merti).

According to the respondent, there is change in farming system in terms of time of planting mainly due to climate change, shifting from one enterprise (both crop and livestock) to another due to awareness change because of change in production goal (from household consumption to market oriented production) and there is also change/shift in enterprise due to disease and pest (for instance shifting from maize and sorghum to teff in Merti and Chole due to striga), while there is shifting of enterprise from pulses and wheat to teff and maize in Dida'a areas due to climate change (late entering of rain and high rainfall which leads to water logging due to large clay content of the soil of the area). There is also shift in enterprise from coffee production to khat (chat) due to poor market development in most coffee producing districts of Arsi except Gololcha district where their coffee is registered and recognized in national market. Most farmers change their dependence on agriculture and shift to non-farm activities like petty trade because of frequent crop failure, farmland shortage and search for better living standards in urban areas (table 18 and 19). 
Table 18. Dimension of Change in Farming System in Arsi zone (farmers' perception).

\begin{tabular}{lll}
\hline No. & Change Dimension & percent of respondent "Yes" \\
\hline 1 & Perceived change in farming system as a whole & 84.20 \\
2 & Change in time of planting & 47.60 \\
3 & Shifting of enterprises (both crop and livestock) & 80.52 \\
4 & Change in ways of production (agronomic practices) & 38.87 \\
5 & Use of improved inputs (both crop and livestock) & 71.54 \\
6 & Production frequency & 9.23 \\
7 & More dependency on crop production than livestock & 81.2 \\
\hline
\end{tabular}

Source own survey data result

Table 19. Cause of Change in Farming System in Arsi zone (farmers' perception).

\begin{tabular}{lll}
\hline No. & Cause of Farming System Change & percent of respondents \\
\hline 1. & Climate change & 25.8 \\
2. & Technological advancement & 53.7 \\
3. & Awareness, skill and knowledge change due to & 60.3 \\
4. & Extension service provision & 87.53 \\
5. & Crop disease & 29.78 \\
6. & Soil fertility decrease due to frequent cultivation, poor & 11.3 \\
7. & Soil and water conservation & 59.5 \\
8. & Use of irrigation facilities & 5 \\
9. & Decrease in grazing land and farmland & 3 \\
\hline
\end{tabular}

\section{Conclusion and Recommendation}

In general about seven farming typologies were identified in Arsi zone each having distinctive characteristics. The first typology was barley-root crops based which is mainly found in highlands of Arsi. The main enterprises were barley, wheat and root crops like potato, beetroots and carrot. The main production constraints were absence of high yielding malt barley, pests (wheat rust), lack of mechanization technologies and varietal options. The second typology was wheat-teff based sub-cluster farming system which is majorly found in mid-highlands/sub-tropics of Arsi zone. The major enterprises are wheat, teff mixed with spices and oil seeds. This sub-cluster is further classified as mechanized and nonmechanized sub-clusters. The main production constraints identified were mono-cropping, climate change, invasive wheat rust and low soil fertility. The third sub-cluster farming typology was a large seeded cereal maize-sorghum based which is found in moderately hot parts of Arsi. The main crops produced are maize, sorghum and haricot bean. Erratic rainfall, crop pests like striga, poor input supply system (fertilizer, seed and chemicals), low level of mechanization technologies use and shortage of draught power were major production constraints of this sub-cluster.

Rain fed coffee-khat (chat)-tree based sub-cluster farming system was the fourth typology found in tropical lowland areas of Arsi zone. Coffee production consists of around 30 percent of total landholding. Other perennial crops like chat, banana and papaya were also the most important enterprises in addition to cereal crops. Erratic rainfall absence of research and development intervention in coffee enterprises, poor soil fertility $\mathrm{b} / \mathrm{c}$ of high erosion and Poor natural resource base (soil and forest) high incidence of coffee diseases poor market system for coffee, poor input supply like seed, fertilizer and chemicals and invasive weeds like striga and other were major production constraints of the area. The fifth sub-cluster was irrigation based farming system typology which is found in all agro-ecologies of the zone. The major crops grown in this sub-cluster were vegetables and fruits. Inputs (pesticides, fertilizers, seed), ineffectiveness of pesticides, high involvement of brokers in output marketing, lack of credit facilities institutional problems like weak water use associations and cooperatives were major constraints. The sixth sub-cluster farming system was pastoral and agro-pastoral typology which is found in lowlands of Arba-gugu areas. The main stay of the area was livestock keeping majorly cattle, goats and camels. Drought was the main constraint of the area which is the main cause for shortage of feed and water. Animal diseases and absence/ shortage of health services were other production constraints. The seventh and last sub-cluster was peri-urban farming system. Two types of farmers exist in this sub-cluster: who work on their own farm and those rent from others living in the town. The first group are well oriented and have good skill and knowledge on farm as their main stay is agriculture while the second group are running farming as secondary activity and though they are using high inputs, they lack skill and knowledge and their productivity is low compared to first group.

In general the research proposals in all disciplines should be developed to tackle each production constraints at each farming typologies. Developing crop varieties that better resist different pests like striga and wheat rusts should be breeders' future plan. Technologies that help farmers to adapt with climate change should be main target and expansion of irrigation technologies to overcome the effect of climate change should be given due attention. Research on development of high yielding varieties of malting barley, demonstration and popularization of intermediate agricultural mechanization technologies should be planned by crop research centers and engineering research centers like Asella. 
Research centers working on coffee like Mechara centers should address production and marketing related constraints of coffee in coffee producing areas of Arsi like Gololcha, Merti, Chole and Shirka districts. development and extension service provider offices should focus on resolving institutional and market problems by strengthening primary input-output marketing cooperatives, credit institutions and regulating illegal input-out marketing in the areas.

\section{References}

[1] FAO. 1994. FARMING SYSTEMS DEVELOPMENT: A participatory approach to helping small-scale farmers.

[2] FAO. 1990. Farming Systems Development: Guidelines for the conduct of a training course in Farming Systems Development. Rome, Italy.

[3] Dixon, J., Gulliver, A., Gibbon, D. 2001. Farming systems and poverty: improving farmers' livelihoods in a changing world. Rome: FAO.

[4] Tittonell, P., Muriukid, A., Shepherde, K. D., Mugendif, D., Kaizzig, K. C., Okeyoa, J., Verchote, L., Coee, R., Vanlauwea, B. 2010. The diversity of rural livelihoods and their influence on soil fertility in agricultural systems of East Africa - A typology of smallholder farms. Agricultural Systems. 103 (2), 83-97.
[5] Chambers, R., Pacey, A., Thrupp, L. A. 1989. Farmer first: farmer innovation and agricultural research, London: Intermediate Technology Publications.

[6] Ojiem, J., Ridder, N., Vanlauwe, B., Giller, K. E. 2006. Socioecological niche: a conceptual framework for integration of legumes in smallholder farming systems. International Journal of Agric. Sustainability. 4(1), 79-93.

[7] Ganpat, W., Bekele, I. 2001. Looking for the trees in the forest: farm typology as a useful tool in defining targets for extension. In: Emerging Trends in Agricultural and Extension Education (J. R. Lindner, ed.), Proceedings of the 17th Annual Conference of the Association for International Agricultural and Extension Education. 4-7 Arpil 2001, Baton Rouge, Louisiana.

[8] Timothy, W. O. 1994. Identifying target groups for livestock improvement research: The classification of sedentary livestock producers in western Niger. Agricultural Systems. 46, 227-237.

[9] Vanclay, J. K. 2005. Using a typology of tree-growers to guide forestry extension. Annals of Tropical Research. 27(1), 97103.

[10] Oromia Bureau of Finance and Economic Development (OBOFED) (2011). Physical and Socio Economic Profile ofArsi Zone and Districts". The National Regional Government of Oromia, Bureau of Finance and d Economic Development -Regional Data and Information Core Process. 